\title{
Layer-by-Layer DNA film synthesis via branched hybridization
}

\section{Les films d'ADN synthétisés via un mécanisme de polymérisation ramifié}

\author{
M. Lazerges ${ }^{a}, H$. Perrot $^{a,{ }^{*}}$, E. Antoine ${ }^{b}$ and C. Compere $^{b}$ \\ a Laboratoire interfaces et systèmes électrochimiques, UPR 15 CNRS, Casier 133, université Pierre-et-Marie- \\ Curie-Paris-VI, 4, place Jussieu, 75252 Paris cedex 05, France \\ ${ }^{\mathrm{b}}$ Service interfaces et capteurs, Ifremer, centre de Brest, B.P. 70, 29280 Plouzané, France \\ *: Corresponding author : H. Perrot, Tel : 33-(0)1-44-27-72-16, Fax : 33-(0)1-44-27-40-74, email
address : $\underline{\text { hubert.perrot@upmc.fr }}$
}

\begin{abstract}
:
A new Layer-by-Layer (LbL) DNA film synthesis, where the driving force is the natural DNA hybridization, is presented in this work. The DNA films were synthesized via a branched mechanism and do not include any chemical binders between each layer as it is the case for film obtained by other synthesis paths. Kinetics of film formation were monitored by mass measurements with an electroacoustic network analyzer. The presented synthesis is a pathway to new DNA structures which can be used in biotechnologies and is complementary to those obtained by other LbL techniques.
\end{abstract}

Keywords: DNA film; Electroacoustic; LbL

\section{Résumé:}

Une nouvelle voie de synthèse de films d'ADN multicouche, ou la force motrice est l'hybridation naturelle de l'ADN, est présentée dans cette étude. Les films d'ADN ont été synthétisés via un mécanisme de polymérisation ramifié et ils n'incluent pas de liants chimiques entre les couches successives comme cela est le cas pour les autres voies de synthèse. Les cinétiques de formation des films ont été suivies par des mesures de masses avec un analyseur de réseau électroacoustique. La synthèse présentée est une voie vers de nouvelles structures d'ADN qui peuvent être utilisées en biotechnologies et qui est complémentaire de celles obtenues par les autres méthodes de synthèse multicouche.

Mots clés: Électroacoustique; Film ADN; Multicouche 


\section{Introduction}

DNA multilayer films [1] have applications in gene delivery [2], biosensors development [3] and bioelectronics [4]. These supramolecular structures obtained from Layerby-Layer (LbL) self-assembly techniques are classically based on alternative deposition of anionic and cationic layers [5,6]. An elegant LbL method that uses DNA hybridization was used to design multilayer DNA structures, but it is limited to homopolymeric blocks [7]. It was recently demonstrated that hybridization in an interfacial environment is enhanced by using well defined DNA strands in order to induce a branched hybridization process [8]. We investigate here the potential of this branched process to synthesize DNA films by a LbL path. A piezoelectric acoustic sensor was used to follow in-situ film formation. This kind of acoustic device, sensitive in the nanogram range, is well adapted to real time monitoring of biomaterial deposition on solid substrate, as it was shown for DNA hybridization [9] in the case of monolayers or polymerase chain reaction [10] in the case of thicker layers. The sensitive area of the sensor is a gold layer deposited on the quartz monocrystal addressed with a network analyzer. Electroacoustic admittances measured around $27 \mathrm{MHz}(9 \mathrm{MHz}$, third overtone) were used to determine both oscillator frequency resonance $\mathrm{f}$ and motional resistance $\mathrm{R}$ that are respectively correlated to mass and energy dissipation in the vicinity of the sensor surface due to film growth. 


\section{Material and Methods}

The acoustic resonator was an AT-cut planar piezoelectric quartz crystal with a $9 \mathrm{MHz}$ resonance frequency (Matel-Fordhal, France). Two $0.2 \mathrm{~cm}^{2}$ gold electrodes were deposited by evaporation techniques on both sides of the quartz crystal with a chromium underlayer. One gold covered quartz surface was cleaned with $10 \mu \mathrm{L}$ drop of $1 / 1 \mathrm{H}_{2} \mathrm{SO}_{4} / \mathrm{H}_{2} \mathrm{O}_{2}$ during 30 minutes. The quartz crystal was mounted between two O-ring seals inserted in a Plexiglas cell. A micropump permits a $50 \mu \mathrm{L} / \mathrm{min}$ constant flow of the DNA solutions in the cell.

Four different DNAs were used to synthesize the film: a 20-base disulfide-labelled DNA A; a 45 base DNA $\underline{A B}$, and two 70-base DNAs $\underline{B C C}$ and $\underline{\mathrm{CBB}}$. A, B, C are 20-base DNA sequences and $\underline{\mathrm{A}}, \underline{\mathrm{B}}, \underline{\mathrm{C}}$ corresponding complementary sequences: A sequence, 5'AGCAC TGATG TGTAA GGGCT-3'; B sequence, 5'-AAAGC TTACT TTTTT GAGCA-3'; C sequence, 5'-AGAAC TTTGT GCCTG GTTCC-3'. A 5-base random DNA spacer sequence 5'-TTGCA-3' is included between each 20-base sequence. The first DNA monolayer is grafted on the gold surface via a strong sulphur-gold bind by circulating $1.7 \mu \mathrm{M}$ disulfidelabelled DNA A in $0.5 \mathrm{M} \mathrm{NaCl}$ solution during two hours. 


\section{Results and discussion}

The LbL synthesis was monitored with the network analyzer by following both series resonance frequency, $\mathrm{f}$, and motional resistance, $\mathrm{R}$, changes during successive circulations $\underline{\mathrm{AB}}, \underline{\mathrm{B} C C}$ and $\underline{\mathrm{CBB}} \mathrm{DNA} 1.7 \mu \mathrm{M}$ solutions in an HEPES buffer $(\mathrm{NaCl} 0.5 \mathrm{M}, \mathrm{pH} 7.2)$ on the sensor surface, as shown on figure 1. Frequency drops during the circulation of successive DNA solutions are attributed to the formation of successive DNA layers as frequency decreases when the mass of the film increases. Motional resistance increases concomitantly, indicating acoustic energy dissipation, as expected for deposition of a soft material, which is the case of a DNA film.

The film was released from the surface by circulation of a $\mathrm{NaOH} 0.5 \mathrm{M}, \mathrm{NaCl} 3 \mathrm{M}$ solution. The frequency in an HEPES solution after the $\mathrm{NaOH}$ circulation is the same as it was before film formation. It means that the disulfide-DNA layer bound to the surface via a strong sulphur-gold interaction remains and allows further film synthesis. This synthesis was successfully done three times to check reproducibility. The four layers film structure deduced from the possible hybridizations reactions is illustrated on the figure 2. The disulfide-labelled DNA used to form the first layer includes a 20-base sequence A. The natural hybridization property of DNA was used to build the film. Successive DNA layers include a DNA sequence complementary to a single stranded sequence of the previous DNA layer: the second layer is constituted with the 45-base DNA $\underline{\mathrm{AB}}$ and further layers with 70-base DNAs $\underline{B} C C$ and $\underline{\mathrm{C} B B}$ in a cyclic fashion. This branched mechanism enhances the hybridization efficiency compared to the linear mechanism which took place when the DNA strands include only two sequences $^{8}$. Diminution of hybridization efficiency in the case of a linear mechanism was attributed to natural folding of DNA strands grafted on the surface. Enhancement of the film formation in the case of a branched mechanism results from two hybridization processes that do not exist in a linear mechanism: the possible hybridization of two DNAs to each DNA strand and to the hybridization of a DNA on a folding DNA strand, as illustrated on the figure 2.

To follow formation of thicker film, only motional resistances changes were considered, as they reach a constant value after three layers deposition, instead of frequency changes which decrease after four cycles due to energy dissipation. A synthesis was performed on the same surface until 19 layers were deposited. Motional resistance variations were recorded during successive circulation of DNA solutions, as shown in figure 3 . The regularity of the motional resistance up-steps indicates regular formation of successive DNA layers during the 17 first steps and a decrease of reactivity during the two last steps. The film 
mass is estimated to $1.9 \mu \mathrm{g}$ taking into account the $350 \mathrm{pg} / \mathrm{Hz}$ sensor mass sensitivity and the frequency variations during the first synthesis steps in which the dissipation energy is minimum. The thickness of the film is estimated to $140 \mathrm{~nm}$, taking into account the length of a bp which is $3.4 \AA$, which is comparable to thickness of film obtained from other LbL synthesis ${ }^{5}$. The film density estimated from the film thickness, mass and area is 0.7. This

value lowering from the 1.7 DNA density based on centrifugation measurements ${ }^{11}$ indicates a diffuse structure of the DNA film.

\section{Conclusion}

We described a LbL DNA film synthesis driven by circulating successive buffered DNA solutions over a solid substrate. The film was synthesized via branched hybridization of two DNAs constituted of three well defined sequences and two identical random 5-base spacers. The DNA structures obtained this way are different and complementary to those obtained by $\mathrm{LbL}$ techniques based on electrostatic interactions. The DNA natural hybridization used to bind successive layers is versatile as it will be possible to control thoroughly the affinity between each layer via the choice of the DNA sequences. The synthesis described is a way to new DNA structures and a new way to DNA films that are currently used in many fields of life sciences, like as biosensors development and bioelectronics.

\section{Acknowledgements}

We wish to thank for financial support ANR-PRECODD through the HAB-SEACHIP project. 


\section{Figure captions}

Figure 1: Frequency $\Delta \mathrm{f}$ (bold line) and motional resistance $\Delta \mathrm{R}$ changes of the piezoelectric sensor during successive circulation of buffered DNA solutions.

Figure 2: Four layers DNA film structure, constituted with DNAs $\mathrm{A}, \underline{\mathrm{A}} \mathrm{B}, \underline{\mathrm{B}} \mathrm{CC}$ and $\underline{\mathrm{C} B B} \mathrm{~B}$ A, $\mathrm{B}$, and $\mathrm{C}$ are 20-base DNA sequences; $\underline{\mathrm{A}}, \underline{\mathrm{B}}, \underline{\mathrm{C}}$ are corresponding complementary 20-base sequences. A black 5-base DNA spacer sequence is included between the 20-base sequences.

Figure 3: Motional resistance variations of the piezoelectric sensor during successive circulation of buffered DNA solutions. 


\section{References}

[1] Lvov Y, Decher G, Sukhorukov G. Assembly of thin films by mean of successive deposition of alternate layers of DNA and Poly(allylamine). Macromolecules 1993 ; 26 : 5396-99.

[2] Zhang J, Chua LS, Lynn DM. Multilayered thin films that sustain the release of functional DNA under physiological conditions. Langmuir, 2004 ; 20 : 8015-21.

[3] Zhou XC, Huang LQ, Li SFY. Microgravimetric DNA sensor based on quartz crystal microbalance: comparison of oligonucleotide immobilization methods and the application in genetic diagnosis. Bios. Bioelec., $2001 ; 16: 85-95$.

[4] Jiang, S, Liu M. A Chiral Switch Based on Dye-Intercalated Layer-by-layer Assembled DNA Film. Chem. Mater., 2004 ; 16 : 3985-87.

[5] Decher G, Hong JD. Buildup of ultrathin multilayer films by a self-assembly process: II. Consecutive adsorption of anionic and cationic bipolar amphiphiles and polyelectrolytes on charged surfaces. Ber. Bunsen-Ges. Phys. Chem., 1991 ; 95 : 1430-34.

[6] Decher G. Fuzzy nanoassemblies: toward layered polymeric multicomposites. Science, 1997 ; 277 : 1232-37.

[7] Johnston APR, Read ES, Caruso F. DNA multilayer films on planar and colloidal supports: sequential assembly of like-charged polyelectrolytes. Nano Lett., 2005 ; 5 : 953-56.

[8] Lazerges M, Perrot H, Rabehagasoa N, Antoine E, Compere C. 45- and 70- base DNA supramolecular polymerization on quartz microbalance biosensor. Chem. Comm., 2005 : 6020-22.

[9] Fawcett NC, Evans JA, Chien L, Flowers N. Nucleic acid hybridization detected by piezoelectric resonance. Anal. Lett., 1988 ; 21 : 1099-1114.

[10] Niikura K, Matsuno H, Ohatake Y. Direct Monitoring of DNA Polymerase Reactions on a Quartz-Crystal Microbalance. J. Am. Chem. Soc., 1998 ; 120 : 8537-38.

[11] Meselson M, Sthal FW. The replication of DNA in Escherichia coli., Proc. Natl. Acad. Sci. USA. $1958 ; 44: 671-82$. 